Original Research Paper

\title{
The Role of Developmental Psychology to Understanding History, Culture and Social Change
}

\author{
Georg W. Oesterdiekhoff \\ Karlsruhe Institute of Technology, Institute for Sociology, PO box 6980, 76128 Karlsruhe, Germany
}

Article history

Received: 28-10-2014

Revised: 29-10-2014

Accepted: 31-12-2014

\begin{abstract}
Developmental psychology of the past generations has evidenced that the whole pre-modern humankind stood on pre-operational or concreteoperational stages. Only the modern humankind has also developed the fourth stage of human development, the adolescent stage of formal operations. Lew Vygotski was 1933 one of the first to earmark convincingly the connection of socialisation (school education) and cognitive development as a precondition to reach the "higher psychological processes", as the Russian school designated what the school of Geneva called "formal operations". The essay documents that developmental psychology is necessary to reconstruct the history of magic, religion, sciences, philosophy, law, morals, politics, economy, population, arts, customs and mentality. It is impossible to understand human's history on earth and social change from Pleistocene up to modern times without developmental psychology. Moreover, the emergence of the formal operations during the early modern times caused the rise of modern, industrial society, including its main parts "industrialism", "sciences", "Enlightenment", "humanism" and "democracy". These five main phenomena of modernity manifest higher stages of psyche and cognition, having arisen in the same region and in the same era. Developmental psychology is able to explain their nature and their internal coherence, while traditional social sciences have no means available to deal with these phenomena, considering their common origination as an accidental phenomenon or misinterpreting it.
\end{abstract}

Keywords: Developmental Psychology, History, Social Change, Modern Society

\section{Introduction}

\section{Developmental Psychology and History}

Societies consist of humans on the one side and surroundings, institutions and things on the other side. Humans, born into a given society, face a world, composed of specific landscapes with specific natural resources, cultivated areas such as soils used for forests, agriculture and cattle breeding, a material world consisting of houses, factories, streets, transport systems and other things and a social world such as families, social classes and political groups. Therefore, social sciences (history, economics, sociology, etc.) treat humans and environment, persons and surroundings, humans and world as well. The differentiation between humans and society is then not the basic distinction but is only an incomplete formula. The most fundamental units of the social sciences are rather humans and world because society is only a part of the world. Philosophers can transform this relationship into a still more abstract language saying that the human existence bases on the relationship between subject and object, inner-world and outer-world, psyche and environment (Oesterdiekhoff, 1997; 2012a).

Against this background, we can discriminate two forms of social sciences or humanities. The materialistic position focuses only on environments and material circumstances, ignoring their subjective constitution and neglecting any historical changes of psyche, reason and consciousness. Shortly, the materialistic approaches treat only "objective phenomena" and overlook "subjective phenomena", assuming, humans would only adopt environmental changes as oxen follow the ploughs they draw. The largest part of the contemporary social sciences belongs to this materialistic group, willingly or 
not, intentionally or not. More or less the whole economy and history and the largest part of sociology and ethnology adhere to the materialistic position (Oesterdiekhoff, 2013a; 2012a).

However, since the era of Enlightenment up to present day influential authors have been emphasizing tremendous changes of psyche, reason and consciousness having taken place during the long history of mankind. There are more or less as many theoretical frameworks of interpreting these changes, as authors have existed, who have tried to describe the alleged transformations. I assign the numerous approaches to two groups at first glance. The first one maintains a historical transformation from primitive, elementary, irrational and archaic forms of reason or psyche to civilized, abstract and rational modes of reason or psyche, having taken place in the early modern times in Europe. The second one stipulates more radically a historical transformation from a childlike psyche to an adult psyche, that is, a parallel between ontogenesis and history. The second position does not refute then the first position but includes and encompasses it. It helps to understand the nature both of primitiveness and civilization, irrationality and rationality, concrete and abstract forms of reason. Additionally, it interprets the transformation from primitive to civilized forms as a transformation from childlike to adult psychological stages. Of course, many authors are not easy to classify because they occupy contradictious or intermediary positions.

To the first group belong many authors such as Max Weber, Émile Durkheim, Bruno Snell, Mircea Eliade, Alexandr Lurija, Lew Vygotski, Wilhelm Wundt, Lucien Lévy-Bruhl, Arnold Gehlen, Jean Gebser and uncountable other authors from 1800 up to now. To the second group belong scholars such as Karl Lamprecht, Jean Piaget, Pierre Janet, Édouard Claparède, Heinz Werner, G. Stanley Hall, James Mark Baldwin, Raoul Allier, Joseph Murphy, Henri Wallon, Charles Blondel, Christopher Hallpike, Charles Radding, Auguste Comte, Norbert Elias and many others. To the intermediary group may belong scholars such as James Frazer, Edward Tylor, Herbert Spencer, Ludwig Feuerbach, Ernst Cassirer, Alfred Vierkandt, William Stern, Sigmund Freud and others (Oesterdiekhoff, 2012a; 2013a; 1997; 2000; 2011; 2012c; Jahoda, 2000).

To my knowledge, the first author in the history of sciences being successful in delivering an encompassing description of the childlike nature of "primitive" or pre-modern man was Heinz Werner. His book Comparative Psychology of Mental Development, written as a German edition already in 1926, as American edition well-known and worldwide available from 1948 onwards, described the parallels between children and pre-modern humans with regard to all relevant aspects of psyche and personality such as causal and logical categories, experience of time and space, understanding reality, magical and mystical ideas, emotions and action patterns, etc.

Jean Piaget, the most impressive and influential developmental psychologist so far, saw child psychology as a laboratory to reconstruct the history of psyche and personality, reason and consciousness, culture, sciences and philosophy. He described parallels between children and ancient philosophy or primitive peoples more or less in all his books. His studies cover the complete world understanding and reasoning of humans, including logic, physics, social affairs and morals. $\mathrm{He}$ and his collaborators described that all humans go through different stages in their way to become adult and mature. The sensory-motor stage of the suckling is followed by the pre-operational stage of the pre-school child from the second year onwards. The third stage of the concrete operations originates during the sixth year of age, manifesting until the tenth year of age. The fourth stage of formal operations unfolds stepwise during the whole course of the second decade of life (Piaget, 1969; 1976; 1975a; 1975b; Mogdil and Mogdil, 1976).

Piaget himself found out that "savages" or "primitive" peoples usually do not establish the stage of concrete operations. He repeatedly defined the stage of concrete operations as typically for the Ionian philosophers. He identified the breakthrough of the adolescent stage of formal operations as key to understand the emergence of sciences in the 17th century. This consideration implies the contention that the formal operations, nowadays characterizing the adolescent's (and adult's) reasoning, may have originated during the early modern times. In his book about morals he compared children's ideas with those of the ancient punishment law (objective and collective responsibility) or of the ancient understanding of the law as an unchangeable part of nature. In his books about children's physics he outlined the similarities regarding the understanding of causality, chance, movements, space, geometry and nature. In his influential book on the worldview of children Piaget described similar ideas about magic, animism and religion children and primitives share (Piaget, 1932; 1959; 1969; 1976; 1975a; Piaget and Garcia, 1989).

The Piagetian Cross-Cultural Psychology (PCCP) was the next step in deepening the insights regarding the parallels between ontogenesis and history. It started in the Thirties, reached its peak probably between 1960 and 1990 and continues up to now. Basing on this research industry, we can overlook the human development in almost all kinds of social settings and cultures around the globe. The surveys demonstrated that all children go through the sensory-motor and pre-operational stages no matter in which culture they are born. Humans, raised in pre-modern, archaic, illiterate, or traditional social milieus, have difficulties in developing already the stage of concrete operations. Only humans living in modernized and industrialized cultures develop the stage 
of formal operations. This result is valid with regard to all logical, physical, social and moral issues, that is, to the whole range of world understanding. This implies that humans of pre-modern societies reach anthropological stages of children only, whereas modern humans alone attain anthropological or psychoneurological stages of adolescents. Primitives differ from children by their knowledge and life experience but share their basic structures of psyche and cognition. Correspondingly, civilized, modern adults share the basic structures with modern adolescents, surmounting only their knowledge and experience (Dasen, 1977; Dasen and Berry, 1974; Eckensberger et al., 1979; Flynn, 2007; Mogdil and Mogdil, 1976; Hallpike, 1980; Piaget, 1976; Poortinga, 1977; Oesterdiekhoff, 1997; 2009a; 2011; 2012b; 2012d; 2013b). Hundreds of researchers have formulated the same conclusion as Ross (1974) did: "It would seem that throughout history many societies have never manifested combinatorial and prepositional logic or the other characteristics of formal thinking."

The Russian socio-historical school is usually not assigned to PCCP. However, both traditions share common test procedures, empirical results and interpretations. Lurija and co-workers did not write that children and primitives (from Usbekistan in 1932) manifest the same structures of reason, but they delivered actually willingly or not clear evidence to this fact (Lurija, 1982; Lurija and Vygotski, 1992). I demonstrated that the Russian school clearly evidenced the parallels between children and primitives especially with regard to logic and reason (Oesterdiekhoff, 2012a; 2013a). I emphasize therefore the assignment of the Russian school to the tradition that researched the parallel between ontogenesis and history.

The field workers of the PCCP had no idea that their empirical results evidenced the earlier findings of Werner, Piaget and others regarding the childlike nature of primitive man and the psychogenetic evolution of modern man. I dare to contend that they did not know at all how to interpret the empirical data. The first researcher who fully recognized the relevance of the PCCP was the ethnologist Hallpike (1980). His book was the first great contribution regarding the parallel of ontogenesis and history since the work of Heinz Werner, that is, since 53 years. Some other authors worked more or less in similar directions such as Habermas (1976; Radding, 1985; Ziégler, 1968; Gablik, 1976; Schöfthaler and Goldschmidt, 1984).

From 1987 onwards I have written eleven books and numerous essays regarding the relationship of developmental psychology and history. I delivered an encompassing summary of PCCP and applied these findings to the reconstruction of the history of humankind and to the rebuilding of the theoretical foundations of humanities and social sciences. I evidenced that the whole pre-modern humankind did not develop the adolescent stage of formal operations apart from very few exceptions. I demonstrated that the social change and the social evolution from the stone ages until the modern era is explainable in terms of developmental psychology. I reconstructed the history of law, arts, literature, philosophy, sciences, religion, magic, morals, customs, politics and economics in terms of developmental psychology. The evolution of formal operations in the early modern times accounts to the emergence of sciences, industrial society, era of Enlightenment, humanism and democracy. These five evolutions took place in the same region and in the same time, namely in the Western culture after 1700 . The rise of anthropological or psychoneurological stages is the common root of these five basic traits that constitute the modern, industrial society. I see in these findings the most radical breakthrough within the social sciences since the days of the classical authors of ethnology, sociology, psychology, history and other disciplines.

The intention of this essay is to demonstrate shortly but concisely the parallels of ontogenesis and history referring the understanding of (1) world and nature, (2) law and morals, (3) politics and democracy and (4) social change and the rise of modern society.

\section{The Evolution of Understanding of Nature and Reality}

\section{From Animism to Mechanics}

Developmental psychology of the past 100 years described that all children understand initially nature and reality, movements and bodies as being animated and alive. They regard stones and toys, lakes and rivers, trees and flowers, houses and cars as living beings, as having a soul and a biological life. They see even stones and rocks as animated, staying still only for a while, but being able to move whenever they want. The whole cosmos is a world of living beings who obey holy rules to play their part in maintaining the order. Children believe that animals have a humanlike mind and could understand what children are speaking and doing. These early trends of animism and anthropomorphism disappear radically with the start of the second decade of life. Children after their tenth year of life develop the empirical-causal categories of reason and the mechanical worldview when the stage of formal operations comes into being. Then they distinguish life and matter, mind and things, biological and physical realities, instincts and consciousness (Piaget, 1959; 1969; 1975a; Werner, 1948; Lurija and Vygotski, 1992).

The ethnology of the past 300 years and related disciplines have described at length that all pre-modern cultures think in the same animistic terms. The primitives do not regard rocks and rivers, forests and stars only as animated and alive, but moreover also as persons and as gods. They adore them and deliver sacrifices to feed them. They regard plants and animals 
as beings being able to think like humans. They see them as magicians and as gods, expect from them help and support. Damaging plants and animals become however victims of blood revenge or judicial trials. Even the European Middle Ages still know trials against all kinds of animals, executed in the same way as trials against human delinquents. The rise of the mechanical philosophy and the natural sciences during the $17^{\text {th }}$ century in Europe formed the first period in history to annihilate animism and anthropomorphism and to establish the stage of formal operations in the minds of the scientific circles. These milieus built the nucleus from where the rise of formal operations started to conquer the whole humankind, a process that has not finished by now (Piaget, 1975b; Piaget and Garcia, 1989; Habermas, 1976; Oesterdiekhoff, 2007; 2009a; 2009b; 2013a; 2011; Lévy-Bruhl, 1927).

\section{From Magic to Rationality}

Developmental psychology describes that magic is an inevitable part of the child's psyche. Children from all cultures cannot avoid regarding nature in magical terms. Not specific traits of the child's psyche account to magic but all phenomena that constitute the child's psyche originate also the magical forms of thinking, for example egocentrism, weak understanding of reality, lack of categories such as causality, chance and probability, wishful thinking and wild fantasy, etc. Magic and child's psyche are two sides of the same medal. Children understand the whole cosmos as made and ruled by magic and they ascribe magical powers to all kinds of objects and beings. Children after their seventh year of life start to reduce magical beliefs; after their tenth year of life they abolish them nearly completely. The formal operations replace magical beliefs by the establishment of the empirical-causal reasoning and the mechanical worldview (Piaget, 1959; 1969; 1975a; Werner, 1948).

Ethnography and related disciplines have documented the central role of magical beliefs and practices across all pre-modern cultures around the globe since the earliest times of mankind by the end of the premodern era. All pre-modern peoples see the world made and ruled by magic and ascribe magical powers to all kinds of objects and beings. Humans, gods, ghosts and objects are believed to steer cosmos and incidents by magic. Magic accounts to all forms of deaths and sicknesses, misfortune and happiness, weather and seasons, epidemics and catastrophes. It is impossible to understand pre-modern cultures without the consideration of the magic's role in their daily activities. The rise of formal operations, mechanical philosophy, physical sciences and the era of Enlightenment in Europe ended the dominance of magic in peoples' thinking. The stage of formal operations replaced magic by rationality in the minds of people during the first generations of the modernizing societies the same way as it does nowadays in the minds of teenagers in the advanced societies (Hallpike, 1980; Evans-Pritchard, 1937, Lévy-Bruhl, 1931; Oesterdiekhoff, 2007; 2009a; 2011; 2012a; 2013a).

\section{From Religion to Agnosticism and Atheism}

Developmental psychology found out that all children tend to religious beliefs due to their psychoneurological stage and related tendencies. Magic and animism constitute some of the core elements of every religion. Gods rule the cosmos by magical powers; this idea expresses the kernel of every religion. Children adore initially their parents (and adults generally) as gods, believed to be able to master household, neighbourhood and world by magic. After their sixth year, modern children run through their first sceptical crisis, discovering increasingly shortcomings of their parents and other adults. They transfer now their religious feelings to the official gods of their culture. Adolescents in modern cultures experience their second sceptical crisis in their $13^{\text {th }}$ year of life and later. They doubt then into the reliability of the established religions, their doctrines and legends and their religiousness dilutes or disappears completely, usually not before their $16^{\text {th }}$ year of life. Additionally, children believe initially in fairy tales especially between their fourth and eighth years of life. Their growing reasoning abilities weaken later on their interest into myths and legends as they surmount magical and animistic beliefs (Bovet, 1951; Piaget, 1959; Werner, 1948).

Feuerbach (1985) was in 1841 the first to develop a comprehensive theory of religion that recognizes the childlike nature of religion. According to Feuerbach, the childlike nature of the pre-modern humankind is the cause to the entire phenomenon of religion, whereas the mature mind of modern man might increasingly tend to agnosticism and atheism. My theory of religion shares this prime idea of Feuerbach but bases on the insights won by the developmental psychology in the past 100 years. Only when humans stay on anthropological stages of children they can fancy myths that describe the existence, personality, biography and actions of gods. The rise of formal operations destroys however the possibility to believe in myths and dilutes or destroys therefore personal relationships with gods. All tribal societies and agrarian civilizations know next to the Olympic gods and godfather ancestor gods, without any known exception. The pre-modern humankind adores their dead fathers, mothers, grandparents, uncles and aunts as gods, omniscient, almighty and being able to rule the lives of their descendants. Only when humans do not pass Bovet's first sceptical crisis but remain largely on the preoperational stage they are able to adore their living or dead older generation. The additional belief in Olympic gods and godfather cannot be much psychologically distant from that family religion described. 
Children have simply not the intellectual capacity to understand the possibility of the total annihilation of the personality after death. Moreover, they have the ability to create imaginary worlds such as heaven and hell, as the primitives do. Only modern adolescents are able to think about the total loss of personality after the physical death. Correspondingly, ethnography documented that primitives have no idea of the inevitability of the physical death. They have actually not the intellectual capacity to understand the end of consciousness and personal life after death. Many historians of religion maintain that the whole pre-modern humankind has believed in a life after death. The idea of the total loss of personality after death came into being as late as the era of Enlightenment. Whereas $90 \%$ of the population in current developing countries believe in the immortality of the soul, only about $50 \%$ of Europeans and Japanese share this belief; the other half denies it. Agnosticism and atheism were born in the era of Enlightenment, too, having now conquered roughly the same percentages in the most advanced countries (Oesterdiekhoff, 2015; 2007; 2011; 2013a; 2012a; 2013b).

\section{From Myths to Sciences}

The mental nutrition for children composed myths and legends. They are keen on them by their eight years of life in modern societies. The children's reasoning abilities are still too weak to understand scientific approaches (Piaget, 1975a; Werner, 1948). Numerous ethnographers document the same phenomenon among primitive peoples. The primitives explain the world and justify their daily activities by myths and legends (Lurija, 1982; Lurija and Vygotski, 1992; Lévy-Bruhl, 1935). Scientific reasoning replaces the role of myths and therefore, it removes religious expositions and justifications. The emergence of sciences took place two times in history. The first rise was bound to the Hellenistic times (essentially 300-100 B.C.), the second rise took place in Europe during the 17th and 18th centuries. The pre-scientific disciplines based on theology, magic, animism and other features of the childlike reasoning. The transition from alchemy to chemistry, astrology to astronomy, magical medicine to scientific medicine, theology to physics, etc., originated during these two centuries. The rise of sciences in the early modern times has therefore only one cause, the breakthrough of the formal operations in the intellectual elite of this age. Piaget himself did a lot to describe the scientific revolution as a breakthrough of the formal operations. He clearly emphasized similarities between pre-modern philosophy and sciences on the one side and the lower stages of cognition on the other side. Piaget and many of his followers have seen the breakthrough of the formal operations as cause to the rise of sciences 350 years ago (Piaget, 1969; 1975a; Piaget and Garcia, 1989; Oesterdiekhoff, 2012a; 2013a).

\section{The Evolution of Law and Morals}

\section{From Ordeals to Trials}

All children believe that incidents and natural phenomena react to the moral behaviour of humans. This so-called belief in the "immanent justice" tends to see every misfortune as caused by moral misconduct and every form of luck as resulting from moral conformity. The objects and occurrences are animated and ruled by the gods as well and monitor, punish or reward always all humans on earth. The child's psyche and adherence to the immanent justice are two sides of the same medal. Animism, magic, theology, lack of categories such as causality, chance and probability, etc. constitute this belief. In Piaget (1932) on the immanent justice, $86 \%$ of the six-years-old, $73 \%$ of the seven-years-old, $54 \%$ of the nine-and-ten-years-old and $34 \%$ of the eleven-and twelve-years-old children supported these assumptions. Only the rise of formal operations eliminates finally this odd link of nature and morals.

PCCP found out that primitive peoples adhere to the immanent justice lifelong, too. Moreover, this childlike reasoning bases the ordeals and oracles, spread right across all pre-modern societies around the globe. The primitives used ordeals and oracles to decide over judicial questions of all kinds, but also for many decisions regarding the planning of everyday activities. The decisions of fire and water, poison and other objects were regarded as true decisions about guilt and innocence. The peoples did not believe in the testimony of eyewitnesses and empirical proofs but rather in the holy decisions of the elements appealed in the judicial ordeals. Tribal societies and agrarian civilizations around the globe used these ordeals roughly to the same rate. The era of Enlightenment was the first in history that abolished these practices completely, of course, due to the rise of formal operations (Evans-Pritchard, 1937; Lévy-Bruhl, 1931; Hallpike, 1980; Oesterdiekhoff, 1997; 2009a; 2011; 2013b; 2013a).

\section{From Objective to Subjective Responsibility}

Children have cognitive difficulties to discriminate intentions from consequences or motives from outcomes. They tend to conclude from bad consequences to bad intentions or overlook the latter ones because they focus on the crucial things, that is, on the influential consequences. The weak reasoning abilities hinder the children from the simultaneous recognition of several factors constituting occurrences. Piaget (1932) called this phenomenon "objective responsibility". According to his own survey, modern children tend to forms of "subjective responsibility" after their tenth year of life due to the rise of formal operations. Of course, the assignment to the two forms depends highly on the complexity of the specific action or occurrence that is just under scrutiny. 
Piaget himself emphasized that the objective responsibility is typical to the law of pre-modern societies, hereby following the related researches of Fauconnet (1920). Numerous historians of law described the transition from the "Erfolgshaftung" to the subjective responsibility for generations. Both ancient legislation and trials often determine persons as guilty for damages they actually did not procure. They tend to punish homicides even then when the accused persons acted unintentionally. Additionally, ancient law adheres to ideas and practices manifesting collective responsibility. Persons are charged and prosecuted for outcomes other persons made. Incidentally, the trials against animals demonstrate fully that the people had enormous difficulties to understand motives and intentions properly. As late as the era of Enlightenment the law became successful to some degree in practising the principles of subjective responsibility (Piaget, 1932; Hallpike, 2004; Oesterdiekhoff, 1997; 2009a; 2009b; 2011; 2013a).

\section{From Savagery to Civilization}

According to Piaget (1932), the younger children always support severe punishments, whereas only the older children and teenagers demand a moderate relationship between faults and punishments. Only the older ones develop an understanding for intentions and errors, while the younger ones want to see punished every misdeed. The younger ones demand revenge, the older ones prefer to accomplish social integration and reconciliation.

The history of the punishment law follows exactly this trend. The modern punishment law composed largely imprisonment and payment, the pre-modern punishment wants to damage the delinquent's body mainly. Theft, robbery, kidnapping, betrayal, rebellion, insult, etc. are very often punished by death penalty. Death penalty is often executed by hanging, decapitating, crucifying, drowning, tearing to pieces, burning, etc. The execution is usually preceded by brutal tortures. The ideas and practices of this sadistic punishment law are very similar or nearly identical in tribal societies and agrarian civilizations around the globe since the stone ages. The Australian aborigines, the black Africans, the ancient Chinese, the Islamic nations and the medieval Europeans practise these punishments more or less the same way. The era of Enlightenment and the European colonialism in overseas were the first steps in world history to abolish this cruel punishment law. The primitive psyche is the single cause to this sadistic system; the psychogenetic maturation is the single cause to its abolishment (Oesterdiekhoff, 2011; 2012a; 2013a).

The Roman arena games consist of gladiator fights, chases of animals and execution of delinquents. Duels, chases and liquidation of criminals are to find however in every pre-modern society. The Roman games differ only by their flamboyant frame, not by their constituting elements. Therefore, the analysis of their culture and spirits is transferable to pre-modern cultures generally. The historical documents display that ancient people loved to see how women were killed by beasts or burnt as torches, how hunches of delinquents slaughtered each other, etc. The state elite sat in the first rows and the middle classes behind. The games stood in the centre of the ancient entertainment culture. If we heard in the TV news nowadays that the Congress had decided to set up an arena in Washington to carry out gladiator fights, execution of delinquents and fights between men and beasts, these news would be more incredible than a broadcast about the landing of some UFO in downtown London.

The primitive psyche is the single cause to the existence of the arena games, the psychogenetic evolution is the single cause to its abolishment. Modern humans could neither sustain nor enjoy these cruelties. This example teaches us about the size and the depth of the psychological distance between ancient and modern man. Both types differ not only in their cognitive structures but in their psyche and personality generally (Oesterdiekhoff, 2009c; 2000; 2011; 2013a; 2012a).

Of course, ancient punishment law and arena games are only some of the many elements that document the lower level of morals and civilization in pre-modern societies. A Third of the pre-modern humankind right across the continents since the stone ages died from homicide, only one per mile in the today's most advanced societies. The relation amounts then 1:333 (Oesterdiekhoff, 2013a). Additionally, I remind the role of cannibalism, slavery and the maltreatment of women and children, to broaden the perspective. The era of Enlightenment and the following times have revealed higher stages of civilization, humanism and morals, originating in the rise of the adolescent stage of formal operations (Hallpike, 2004; Porter, 2001; Rüsen, 2013; Elias, 1982).

\section{The Evolution of State, Government and Politics}

\section{From Authoritarianism to Democracy}

The developmental psychology of the past 100 years found out that small children prefer authoritarian forms of social relations. The adherence to a law-and-orderstate is intellectually easier than the consideration of the complex conditions constituting liberty rights and democratic principles. Small children see democracy as chaos and a strict hierarchy as precondition to order. The rise of the adolescent stage of formal operations is necessary to arouse the principles of democracy and constitutional state (Piaget, 1932; Selman, 1980; Damon, 1983; Adelson and Bell, 1970; Tapp and Kohlberg, 
1971; Durio, 1976; Oesterdiekhoff, 2013b). Moreover, developmental psychology is crucial for the reconstruction of the history of political institutions, customs and ideologies. Rosenberg et al. (1988) wrote that developmental psychology may deliver the main theory of the political sciences: "We therefore conclude that only genetic-epistemological theories currently provide the psychological theory and cross-cultural validity (not to mention the normative support) required for a normative-psychological theory underlying a general political development."

Piaget (1932) delivered probably the first great contribution to the discovery of the cognitivedevelopmental origins of democracy. In his great analysis of the children's marble game he discovered three stages of rules. The second stage consists both of the idea of the holy and unchangeable status of the rules and an egocentric and incompetent practice. The children aged 5-10 assume that the rules may exist for eternity, founded by god, ancestors, or elderly and not exposed to the changing will of players. However, the children this age have only a scanty knowledge of the rules and make many faults in applying them. The children of the third stage then, now belonging to the second decade of life, surmount both the idea of the holy status and the bad usage. They establish the idea and practice of the democratic constitution of the rules and are keen on their proper and fair application to the same rate.

PCCP found out that pre-modern peoples around the world are staying on the second stage of rule understanding, when exposed to the related Piagetian test procedures (Oesterdiekhoff, 2009a; 2013a). As surveys reveal abundantly, pre-modern peoples prefer willingly authoritarian forms of political order and reject democracy (Oesterdiekhoff, 2013b). Not social constellations and institutional powers cause therefore the universality of authoritarian forms such as monarchy, dictatorship, tyranny and aristocracy in the pre-modern world but the will of the people itself, staying on the second stage.

The Islamic nations of today (apart of Turkey) are more or less typical examples of the combination of the divine status of the state and a simultaneous horrible political practice. God or Mohammed themselves are believed to determine legislation and government, through their representatives such as kings, dictators, or presidents. The civil sphere of these Islamic nations is however characterized by the maltreatment of all kinds of civil rights, lack of freedom and security of people. A sufficient proof of this thesis lies in the fact that the Shari'a forms the centre of the Islam policy. The political Islam believes that the execution of the Shari'a laws be eminent to erect the Islamic state, with all advantages such as peace, wealth, order and world dominance. The Shari'a however is nothing else than the sadistic punishment law I outlined above. The same combination of divine government and terrible civil sphere is documented referring the pre-modern China, India, medieval Europe and the Roman Empire. Piaget's theory is therefore fundamental to the understanding of the political life of the pre-modern world, as I detailed in my latest book more precisely as it is possible here (Oesterdiekhoff, 2013a).

The historian Kern (1952) characterized the political life of the medieval times with the same words Piaget used to describe the second stage. Both authors did not know each other, though. Kern said medieval politics and legislation would combine a holy ideology and a divine understanding of the political practice with an actually dismal practice. Though, the political practice of all pre-modern societies consists of corruption, violence, brutality, exploitation, lack of human rights, insecurity and waste of life to a horrible extent. Only the modern constitutional state and the modern democracy have done a lot to improve social conditions, liberty rights, security and to guarantee welfare and peace. It is obvious that the rise of the adolescent stage of formal operations, that is the cognitive rise of social cognitions, empathy and morals, is the ultimate cause to the evolution of sociomoral standards and to the improvements of the civil sphere. The social life and the public affairs within the modern societies base on the third stage Piaget described in 1932 (Oesterdiekhoff, 2009a; 2013a).

Consequently, the modern transformation to constitutional state, democracy and liberty rights does not stem from changing class constellations but from the will of the people to establish forms of freedom and security. The era of Enlightenment worked out the ideas of democracy and constitutional state (especially Locke, Montesquieu and Rousseau) because the rise of the adolescent stage of formal operations took place in the educated classes in the Western culture in this time, as I outlined above. The revolutions in the United States, England and France erected democratic structures, ending the pre-modern forms of government and legislation in an unprecedented way. From this nucleus both of psychogenetic evolution and democratic policy started these new forms of political life to conquer the whole world, not having yet accomplished this task by now (Oesterdiekhoff, 2009b; 2013b). Developmental psychology is therefore fundamental to the political sciences and to the reconstruction of the history of political relations, civil life, government and legislation. Whenever a whole population is staying on Piaget's stage two, authoritarian political forms dominate, leaving no chance to democracy and liberty rights. Modern, formal-operational populations, staying on stage three, would never accept dictatorship as they do not accept ancient laws of punishment. Moreover, they may assume wrongly all 
peoples would prefer democracy, at least deep in their minds and hearts. However, surveys in pre-modern peoples and developmental research teach otherwise.

\section{From Serfdom and Slavery to Liberty and Egalitarianism}

Serfdom and slavery go back to pre-history and lasted up to the beginning of modern times, up to the era of Enlightenment and to the rise of modern society right across the continents during the past two centuries. Slavery and serfdom existed among the natives of preColumbian America, among the ancient Germans, in Black Africa, China, India, Russia and Greek-Roman antiquity. The first nations to abolish slavery and serfdom were the European nations around 1800 and later on. Not changes of economy and social structure forced the Royal Navy to ban the slave trade on the oceans but the humanistic ideas born in the era of Enlightenment. The same cognitive revolution that originated the ideas of political democracy supported the ideas concerning liberty and freedom, banning all forms of serfdom and slavery. The revolution of morals and humanism surmounted the barbarian social relations existing for millennia around the globe. To say it clearly, the psychogenetic evolution of formal operations is the ultimate cause to the abolishment of primitive social relations such as slavery and serfdom (Porter, 2001; Oesterdiekhoff, 2013a; 2009a).

\section{Social Change and the Rise of Modern, Industrial Society}

Man spent most of his time on the planet, roughly 200.000 years, as hunter and gatherer, before he changed to agriculture, cattle breeding, housing and village life. Since 1965 roughly, the research on the agrarian transformation in the Neolithic era earmarks mainly the increasing population growth and density as main or single cause to this decisive socio-economic transformation. Around 10.000 B.C., the world population grew to 5-10 millions (Oesterdiekhoff, 1993; 2005). The question arises why did the humankind need 200.000 years to fill the continents with a number that makes now only a part of Moscow? Had every stone age-woman born and raised children only a little bit more successful than the humankind would have reached the critical mass of 10 millions shortly after the origination of the species. The necessity to change the systems of production would have arisen 200.000 years earlier than it actually did. The whole chain of agrarian and industrial transformations would have taken place earlier. The human species had obviously severe problems in mastering nature and social life. When biologists leave some rats on a new continent spread they probably more successfully. The answer to the question is that the Pleistocene hunters had not the intellectual capacity as modern humans have. If we only removed (in a theoretical consideration) the fatal effects stemming from magic, as a part of the pre-operational stage, or cannibalism, from the hunter's psyche, he would have propagated much stronger. Consequently, the fact of the pre-operational stage of the Pleistocene man is the main cause to his weak spread on earth and to the length of the Pleistocene era. Developmental psychology sheds therefore a new light on the Pleistocene and the Neolithic eras (Oesterdiekhoff, 2013b; 2011; 2012b).

The lower psychoneurological stages account also for some main characteristics of the subsequent village societies and agrarian civilizations as I outlined elsewhere. Though, the shortage of place here forces to focus on one of the main interesting research questions of the social sciences, namely the question into the causes of the rise of the modern, industrial society. The facts show that the whole pre-modern humankind stood on childlike anthropological stages, whereas only the modern populations developed the adolescent stage of formal operations. This phenomenon suffices alone to emphasize the role of the psychogenetic evolution to the rise of modern society.

When we think about the main characteristics of the modern, industrial society we have to consider causes and nature of "industrialism", "sciences", "Enlightenment", "humanism" and "democracy". All these five main features of the modern, industrial society came into being in the same culture and in the same era, namely in the Western culture after 1700. Their coevolution cannot be accidental but has to be rooted in the same source. "Enlightenment", "sciences" and "humanism" are not material and institutional phenomena but intellectual phenomena, moreover such, which manifest a cognitive evolution or progress. Therefore, it is already at first glance probable that also the two other main features, "industrialism" and "democracy", had cognitive origins.

I outlined above that Piagetian research described the rise of formal operations as the cause to the rise of sciences in the early modern era. As Jacob (1997) evidenced, the new physical sciences such as chemistry and physics gave birth to the industrial technologies such as the steam engine of Watt and Boulton. Watt was a scientist belonging to the top elite of researchers of his time. The steam engine, characterizing the difference between pre-industrial and industrial society, was beyond the technological possibilities of Asia and Greek-Roman antiquity as well. Besides, "sciences" are only one of the many manifestations of the formal operations causing and carrying industrial economy (Oesterdiekhoff, 2011; 2013a; 2012a). The rise of the era of Enlightenment is rooted in the rise of formal operations, too. The enlightened scholars fought against 
magic, superstition and religion on the one side and against slavery, exploitation and tyranny on the other side. It needs no commentary that the emergence of the era of Enlightenment evidences the rise of the formal operations in the educated classes. Moreover, while the rise of the natural sciences documents the rise of formal operations in the realm of physics, the rise of the era of Enlightenment indicates also the rise of the adolescent stage in the area of socio-moral judgments and sentiments. This leads automatically to the consideration of the phenomenon "humanism". As I displayed above, the abolishment of the brutal punishment law, slavery and feudalism around 1800 was rooted in the rise of the adolescent stage of formal operations, thus including the rise of socio-moral standards, empathy and emotions. Moreover, this rise of humanism and socio-moral standards forced the humans to establish social rules and moral codes that ban all forms of political tyranny. Humans on higher stages manifest higher stages of selfrespect and respect of others, dignity, freedom and security. They do not want treat other persons as slaves and do not want to be treated themselves this way. I showed above sufficiently that the emergence of formal operations originated the rise of democracy. Humans on childlike stages prefer authoritarian forms, whereas humans, staying on the fourth stage, demand elaborate forms of social and political life, that is, constitutional state and democracy, freedom and liberty rights.

The rise of formal operations having taken place during the early modern times originated industrialism, sciences, humanism, Enlightenment and democracy. Developmental psychology is able to explain the inherent link between these five phenomena and therefore, why these five phenomena came into being at the same time and in the same culture or region. The traditional sociology has no tools available to explain the common features of these five phenomena and therefore, why they emerged at the same time and in the same place. These considerations lead to the conclusion that the rise of anthropological summits for 5, 10, or even more years and the rise of modern, industrial society are two parts of the same medal. Humans staying on childlike stages live in pre-modern societies; humans erecting the fourth stage of human development build up the modern, industrial society, thus establishing the greatest transformation of society and culture since the Neolithic times (Oesterdiekhoff, 2011; 2013a; 2012a).

My theory of the rise of modern society express a considerable improvement of ideas Piaget, Habermas, Hallpike and Ziégler had already formulated. Moreover, it shares basis thoughts A. Comte and N. Elias had written down. Both classical authors had contended a tight relationship between psychogenesis and the rise of modern society. My theory also shares ideas of $\mathrm{M}$.
Weber and É. Durkheim, J. Lubbock and H. Spencer, E. Tylor and some other authors. However, the new theory earmarks the decisive phenomena much more exactly than all these preceding approaches had already done.

\section{Conclusion}

My new theory, developed in the past 30 years and named "structure-genetic sociology", has accomplished the life task and life work of Jean Piaget. It has finished the work Piaget started and aimed to do. Current developmental psychologists usually do not know what every (!) classical developmental psychologist had already known, namely, that developmental psychology concerns not only children but also the primitives (the humankind). I have shown that developmental psychology is the fundamental psychology to understand humans and societies right across history and continents. Developmental psychology and Völkerpsychologie are synonyms. Developmental psychology is the most fundamental historical anthropology, historical psychology, or micro-sociology. Without developmental psychology it is impossible to understand human's psyche and behaviour in history and culture.

Moreover, developmental psychology is necessary to reconstruct human's history on earth and social change and social evolution from the Neolithic era to modern times. It explains the length of the stone ages, the peculiarities of pre-modern societies and the rise of the modern era.

The fact of the childlike stage of primitive humans and of the anthropological rise of modern humans for 5 , 10 , or more years is the most fundamental, fascinating and surprising phenomenon the social sciences and the humanities have ever raised in their history. Current social sciences know nothing about this phenomenon although the great researchers especially of the Twenties and Thirties of the past century worked in the direction to understand these coherences. The philologist Schneider (1909) prognosticated that the discovery of the role of developmental psychology to the humanities would revolutionize them and bring them on a higher level comparable to that of the biology in consequence of Darwin's revolution. Developmental psychology and evolutionary cultural anthropology originated somewhat in Darwinian theoretical circles. Darwin (1998) himself demanded a evolutionary theory of mind, already hinting to the possibilities child psychology could offer and assuming ancient man might have been more childlike than modern man. He even contended that the Roman games would reveal lower anthropological stages of cognition and morals, a phenomenon, I evidenced clearly above.

Therefore, I actually regard my structure-genetic sociology as that theory programme that founded social sciences and humanities on new pillars, stronger and 
higher erecting from the swamp of mere opinions than the current streams of theories are expressing. The new theory programme bases simultaneously on ethnology, sociology, psychology and history as the classical theories of Comte, Durkheim, Lubbock and Spencer did, as additionally at least partly the theories of Weber and Elias did. An encompassing and thorough theory of the development of humankind and culture has to be built on these four disciplines; otherwise it fails certainly. The sociological and ethnological theories of the past 50 years did not base on these broad and necessary disciplines but on tight approaches and misinterpreted knowledge. In this essay, I outlined the alternative and the remedies necessary for a recovery of the social sciences and humanities from the Dornröschenschlaf of the past generations. Structuregenetic sociology or developmental psychology is not only necessary for the recovery of the four disciplines mentioned but for all historical disciplines, for nearly all social sciences and humanities, namely for all those that treat human's history.

\section{Funding Information}

The authors have no support or funding to report.

\section{Author's Contributions}

All authors equally contributed in this work.

\section{Ethics}

This article is original and contains unpublished material. The corresponding author confirms that all of the other authors have read and approved the manuscript and no ethical issues involved.

\section{References}

Adelson, J. and L. Bell, 1970. Adolescent perspectives on law and government. Law Society Rev., 4: 495-504.

Bovet, P., 1951. Le Sentiment Religieux et la Psychologie de l'enfant: Pierre Bovet. 2nd Edn., Delachaux et Niestlé, Neuchâtel, pp: 174.

Damon, W., 1983. Social and Personality Development. 1 st Edn., W. W. Norton and Company, New York.

Darwin, C., 1998. The Descent of Man. 1st Edn., Prometheus Books, New York.

Dasen, P. and J.W. Berry, 1974. Culture and Cognition: Readings in Cross-Cultural Psychology. 1st Edn., Methuen and Company. London, pp: 487.

Dasen, P., 1977. Piagetian Cross-Cultural Psychology. 1st Edn., Gardner Press New York.

Durio, H.F., 1976. A taxonomy of democratic development. Human Dev., 19: 197-219.

DOI: $10.1159 / 000271529$
Eckensberger, L., W.J. Lonner and Y.H. Poortinga, 1979. Cross-Cultural Contributions to Psychology. 1st Edn., Garland Science, ISBN-10: 9026503008, pp: 441.

Elias, N., 1982. Power and Civility. 1st Edn., Pantheon, New York, ISBN-10: 0394527690, pp: 376.

Evans-Pritchard, E.E., 1937. Witchcraft, Oracles and Magic Among the Azande. 1st Edn., University Press, Oxford.

Fauconnet, P., 1920. La Résponsabilité. 1st Edn., Alcan, Paris.

Feuerbach, L., 1985. The Essence of Christianity. 1st Edn., Harper and Collins, New York.

Flynn, J., 2007. What is Intelligence? 1st Edn., University Press, Cambridge.

Gablik, S., 1976. Progress in Art. 1st Edn., Thames and Hudson, London.

Habermas, J., 1976. Zur Rekonstruktion des Historischen Materialismus. 1st Edn., Suhrkamp Verlag, ISBN-10: 3518277545 , pp: 346.

Hallpike, C.R., 1980. Foundations of Primitive Thought. 1st Edn., Oxford University Press, ISBN-10: 0198231962, pp: 530 .

Hallpike, C., 2004. The Evolution of Moral Understanding. 1st Edn., PRG, London.

Jacob, M.C., 1997. Scientific Culture and the Making of the Industrial West. 1st Edn., Oxford University Press, New York, ISBN-10: 0195082206, pp: 269.

Jahoda, G., 2000. Piaget and levy-bruhl. History Psychol., 3: 218-238. PMID: 11624594

Kern, F., 1952. Recht und Verfassung im Mittelalter. 1st Edn., Wissenschaftliche Buchgesellschaft, Darmstadt, ISBN-10: 3534000358, pp: 111.

Lévy-Bruhl, L., 1927. L'âme Primitive. 1st Edn., Alcan, Paris.

Lévy-Bruhl, L., 1931. Le surnaturel et la Nature Dans la Mentalité Primitive. 1st Edn., Alcan. Paris.

Lévy-Bruhl, L., 1935. La Mythologie Primitive. 1st Edn., Alcan, Paris.

Lurija, A.R. and L.S. Vygotski, 1992. Ape, Primitive Man and Child Essays in the History of Behavior. 1st Edn., CRC Press, ISBN-10: 1878205439, pp: 186

Lurija, A.R., 1982. Cognitive Development: Its Cultural and Social Foundations. 1st Edn., Harvard University Press, Cambridge, ISBN-10: 0674137329, pp: 175.

Mogdil, S. and C. Mogdil, 1976. Piagetian Research. INFR, London.

Oesterdiekhoff, G.W., 1993. Die Rolle des Bevölkerungswachstums in Der Sozialökonomischen Entwicklung. 1st Edn., Wiss.Verlag Vauk, ISBN-10: 3817501420, pp: 99.

Oesterdiekhoff, G.W., 1997. Kulturelle Bedingungen Kognitiver Entwicklung: Der Strukturgenetische Ansatz in der Soziologie.1st Edn., Suhrkamp Verlag, ISBN-10: 3518288830, pp: 325. 
Oesterdiekhoff, G.W., 2000. Zivilisation und Strukturgenese: Norbert Elias und Jean Piaget im Vergleich. 1st Edn., Suhrkamp Verlag, ISBN-10: 3518290614, pp: 407.

Oesterdiekhoff, G.W., 2005. Entwicklung der Weltgesellschaft: Von der Steinzeit Zur Moderne. 1st Edn., LIT, ISBN-10: 3825889602, pp: 348.

Oesterdiekhoff, G.W., 2007. Ancient sun cults: Understanding religious rites in terms of developmental psychology. Mank. Q., 48: 99-116.

Oesterdiekhoff, G., 2009a. Mental Growth of Humankind in History. 1st Edn., BoD-Books on Demand, Norderstedt, ISBN-10: 3837093182, pp: 456.

Oesterdiekhoff, G.W., 2009b. Trials against animals: A contribution to the developmental theory of mind and rationality. Mank. Q., 3: 346-380.

Oesterdiekhoff, G.W., 2009c. The arena games in the roman empire: A contribution to the explanation of the history of morals and humanity. Croat. J. Ethnol., 46: 177-202.

Oesterdiekhoff, G.W., 2011. The Steps of Man Towards Civilization. 1st Edn., Books On Demand, ISBN-10: 3842342888, pp: 238.

Oesterdiekhoff, G.W., 2012a. Die geistige Entwicklung der Menschheit. Velbrück Verlag, Weilerswist.

Oesterdiekhoff, G.W., 2012b. Was pre-modern man a child? The quintessence of the psychometric and developmental approaches. Intelligence, 40: 470478. DOI: $10.1016 /$ j.intell.2012.05.005

Oesterdiekhoff, G.W., 2012c. Ontogeny and history the leading theories reconsidered. Cultural-Historical Psychol., 3: 60-69.

Oesterdiekhoff, G.W., 2012d. The rise of formal operations in history. Psychol. Sci. Educ., 3: 1-13.

Oesterdiekhoff, G.W., 2013a. Die Entwicklung der Menschheit von der Kindheitsphase zur Erwachsenenreife. 1st Edn., Springer-Verlag, ISBN-10: 3531197274, pp: 626.

Oesterdiekhoff, G.W., 2013b. Relevance of piagetian cross-cultural psychology to the humanities and social sciences. Am. J. Psychol., 126: 477-492. PMID: 24455813

Oesterdiekhoff, G.W., 2015. Traumzeit der Menschheit: Wesen, Ursprung und Untergang der Religion. 1st Edn., Springer, Wiesbaden.

Piaget, J. and R. Garcia, 1989. Psychogenesis and the History of Science. 1st Edn., Columbia University Press, New York, ISBN-10: 0231059922, pp: 309.

Piaget, J., 1932. The Moral Judgment of the Child. 1st Edn., Kegan, Trench, Trubner and Co., New York.

Piaget, J., 1959. The Child's Conception of the World. 1 st Edn., Littlefield, Adams and Co., Totowa.
Piaget, J., 1969. The Child's Conception of Physical Causality. 1st Edn., Littlefield, Adams and Co., Totowa, New Yersey.

Piaget, J., 1976. Need and Significance of Cross-Cultural Studies in Genetic Psychology. In: Piaget and His School: A Reader in Developmental Psychology, Inhelder, B., H.H. Chipman and C. Zwingmann (Eds.), Springer, London, ISBN-10: 0387072489, pp: 259-268.

Piaget, J., 1975a. Gesammelte Werke: Zehn Bände. Klett Verlag, Stuttgart.

Piaget, J., 1975b. The Origin of the Idea of Chance in Children. 1st Edn., Routledge and Kegan Paul, London, ISBN-10: 0710082002, pp: 249.

Poortinga, Y.H., 1977. Basic Problems in CrossCultural Psychology. 1st Edn., Swets and Zeitlinger, ISBN-10: 9026502478, pp: 380.

Porter, R., 2001. The Creation of the Modern World: The Untold Story of the British Enlightenment. 1st Edn., Norton and Company, New York, ISBN-10: 0393322688, pp: 727.

Radding, C., 1985. A World Made by Men: Cognition and Society, 400-1200. 1st Edn., University of North Carolina Press, Chapel Hill, ISBN-10: 0807816647, pp: 286.

Rosenberg, S., D. Ward and S. Chilton, 1988. Political Reasoning and Cognition: A Piagetian View. 1st Edn., Duke University Press, ISBN-10: 0822308568, pp: 204.

Ross, R., 1974. The empirical status of formal operations. Adolescence, 9: 413-427.

Rüsen, J., 2013. Approaching Humankind: Towards an Intercultural Humanism. 1st Edn., Vandenhoeck and Ruprecht, Göttingen, ISBN-10: 3847100580, pp: 300.

Schneider, H., 1909. Kultur und Denken der alten Ägypter. 1st Edn., Hinrichsche Buchhandlung, Leipzig, pp: 564.

Schöfthaler, T. and D. Goldschmidt, 1984. Soziale Struktur und Vernunft. 1st Edn., Suhrkamp, Frankfurt am Main, ISBN-10: 3518279653.

Selman, R., 1980. The Growth of Interpersonal Understanding. Academic Press, New York, ISBN-10: 0126364508, pp: 343.

Tapp, J. and L. Kohlberg, 1971. Developing senses of law and legal justice. J. Soc. Issues, 27: 65-91. DOI: $10.1111 / \mathrm{j} .1540-4560.1971 . t b 00654 . x$

Werner, H., 1948. Comparative Psychology of Mental Development. 1st Edn., Follet, Chicago.

Ziégler, J., 1968. Sociologie et Contestation. 1st Edn., Gallimard, ISBN-10: 2070351920, pp: 252. 